\title{
A quality framework for assessing the designed curriculum - a basis for the Czech PE curriculum revision
}

Petr Vlček

Faculty of Education, Masaryk University in Brno, Czech Republic

vlcek@ped.muni.cz

\section{ABSTRACT}

This paper presents a general curriculum quality framework that has been developed on the basis of research in the Czech Republic and internationally. The cogency of this framework and its relevance to the Czech PE curriculum is demonstrated by reference to curriculum research. Finally its potential as a quality assessment tool for the review of the Czech Physical Education curriculum is discussed.

\section{KEYWORDS}

curriculum quality; curriculum quality characteristics; curriculum review; physical education curriculum; the Czech Republic

DOI

$10.14712 / 23366052.2020 .6$

(c) 2020 The Author. This is an open-access article distributed under the terms of the Creative Commons Attribution License (http://creativecommons.org/licenses/by/4.0), which permits unrestricted use, distribution, and reproduction in any medium, provided the original author and source are credited. 


\section{INTRODUCTION}

Since the fall of communism in the Czech Republic in 1989 significant educational reforms have taken place, including major reform of the Czech school curriculum. The current national curricular documents (the Framework Educational Programmes - FEPs) were issued from 2005 onwards for the different levels of education.

The general Czech curriculum, in its concept and design, is perceived as problematic (e.g. Dvořák, Starý, \& Urbánek, 2015; Janík, 2013; Janík et al., 2018, 2019; Kuhn, 2011, etc.). According to Šíp (2014), this is due to the inadequacies of the reform process and the fact that the strengths and weaknesses of the original curriculum were not clearly established prior to the reforms. We agree with this view (c.f. Kuřina, 2014; Vlček, 2019) and also believe that the changes were not sufficiently discussed beforehand, with academic experts, in schools or with teachers. This might be the reason behind the unsatisfactory outcomes of the curricular reform and the failure to accept some changes.

There is also a large body of research, which indicates that the physical education (PE) curriculum in the Czech Republic is not working as it should (Habrdlová, Lupač \& Vlček, 2017; Lupač, 2016; Habrdlová \& Vlček, 2015; Mužík \& Vlček, 2016; Tupý, 2018; Vlček \& Mužík, 2012; Vlček, 2019). From the reform's beginning, a health concept underpinned the Czech PE designed curriculum. Despite the fact that the programmes have been shown to be problematic (Mužík \& Vlček, 2016) and have been subject to ongoing content reviews, approved by the Ministry of Education and Sport (MEYS), the health oriented concept of the Czech PE curriculum has not changed significantly and in fact in educational practice different $\mathrm{PE}$ concepts still prevail (Fialová, Flemr, Marádová, \& Mužík, 2014; Vlček, 2019). The research also shows that there is a lack of internal congruence in the PE curriculum between the health-oriented learning objectives and the more balanced educational content (health/movement) and that the health-oriented PE concept is not accepted by the public and is not being implemented by teachers (cf. Fialová et al., 2014; Vašićcková, 2016; Janík, Vlček, \& Mužík, 2016).

In 2018 the MEYS has announced a new cycle of revision for the Czech FEPs which will also affect the PE designed curriculum. This project is now referred to as Revision of the FEP and preparation of the Education Policy Strategy of the Czech Republic until $2030+\left(\right.$ Strategy 2030+) ${ }^{1}$. In January 2019 an expert group was established under the leadership of Prof. Arnošt Veselý. Their task is to prepare the initial document Guidelines for Education Policy of the Czech Republic 2030+ to define the vision, priorities and objectives of education policy beyond 2030. It will describe what should be achieved and how these goals can be achieved.

For the purposes of the review it is important that the quality of the existing curriculum is assessed but the question is how, and what tools can be used. In 2011 an interdisciplinary team, which included the author, conducted an expert survey of experienced directors (head-teachers) and teachers in grammar schools ${ }^{2}$, to hear direct-

For more information see http://www.nuv.cz/t/rrvp.

A grammar school is a selective high school at the stage of upper secondary education typically beginning at age 15 or 16 years (ISCED 3). 
ly from experts in the field regarding what makes a quality designed curriculum (Janík et al., 2011). These results were combined with similar studies conducted in the Czech Republic and abroad (Böttcher, 2006; Dvořák, 2012; Dane \& Schneider, 1998; Egger et al., 2002; Gehrmann, Hericks, \& Lüders, 2010; Gandal \& Vranek, 2001; Halbheer \& Reusser, 2008; Havel, 2016; Kurz, 2005; Squires, 2012, 1998; Stake, 1967, 1972; Thijs \& Van den Akker, 2009; Zhu, Ennis, \& Chen, 2011) and a general quality framework developed (Janík et al., 2011).

Unfortunately, this framework has not been used in discussions about the PE curriculum quality in the Czech Republic. This paper presents this quality framework and discusses its applicability as a potential assessment tool for the planned PE curriculum revision in the Czech Republic.

\section{To the Curriculum and its quality}

It is important to note that the term curriculum is not defined consistently by different researchers. In a narrow definition, a curriculum means a teaching program. In the broadest sense, the curriculum means all the learning that takes place at school or in other institutions, both planned and unscheduled (cf. Lawton \& Gordon, 1993, p. 66). In this text we view the 'curriculum' as somewhere between these extremes.

We distinguish five forms of the curriculum (Průcha, 2002):

- Concept form - vision, rationale or 'basic philosophy' underlying a curriculum.

- Designed form - official documents (e.g. syllabi) prescribed at both the government level (the educational framework) and at the school level, but also and associated teaching materials, text books, etc.

- Implemented form - curriculum as interpreted and used (especially by teachers).

- Results form - outcomes of the actual process of teaching and learning.

- Effects form - the impact of the acquired and attained learning outcomes on learners.

Frequently in discussion of the curriculum only the designed form is considered. However, in any quality assessment it is not sufficient to consider just the designed form of the curriculum - all five forms must be taken into account.

Janík et al. (2013, p. 20, cf. Průcha, 1996, pp. 26-27; Helmke, 2007, p. 40) distinguish two different meanings of the term 'quality' (cf. the Oxford definition of quality ${ }^{3}$ ).

1) A descriptive meaning which identifies a desirable characteristic or attribute of a pedagogical phenomenon, for example the practicality of a designed curriculum.

2) An evaluative meaning which describes a desirable standard or optimal level of achievement. This involves setting targets using normative approach as defined by Terhart, (2000, pp. 815-816) and their evaluation and measurement using an empirical approach - (Terhart, 2000, p. 817) as for example used in PISA (Programme for International Student Assessment) and TIMSS (Trends in International Mathematics and Science Study).

In this text we use the first definition. This means that quality can be viewed as a complex entity that can be broken down into specific attributes. Through monitoring and evaluation of these attributes, the problematic aspects of a curriculum can be identified (Janík et al., 2013, p. 21).

3 www.lexico.com/en/definition/quality 


\section{The Quality Framework}

The framework presented here, developed by Janík et al. (2011), was developed to define the general characteristics of a quality designed curriculum. It comprises specific quality criteria grouped within four key areas ${ }^{4}$. These key areas provide an overall quality framework and the detailed quality criteria describe these areas more comprehensively.

- Area 1: feasibility and practicality

Criteria/characteristics:

1.1 respects reality and is manageable,

1.2 respects teaching/learning practice and is practical,

1.3 is instructive, inspirational and motivating for teachers,

1.4 is usable in the school environment by managers and teachers,

1.5 encourages communication and cooperation in school.

- Area 2: professional accuracy and congruence

Criteria/characteristics:

2.1 is consistent with similar documents such as assessments and inspection criteria,

2.2 is logical and interconnects goals and educational content,

2.3 accurately reflects the relevant discipline and the current state of disciplinary knowledge.

- Area 3: clarity and comprehensibility

Criteria/characteristics:

3.1 is thoughtfully structured and well-arranged,

3.2 is written so that it is accessible, understandable and accepted,

3.3 it is structurally interconnected,

3.4 it is concise but includes the essentials.

- Area 4: flexibility within overall bindingness

Criteria/characteristics:

4.1 provides a reasonable space for free decision-making,

4.2 is durable but provides flexibility for updating educational practice,

4.3 provides a desirable degree of uniformity between schools,

4.4 it defines what is important for pupils to acquire (the core curriculum) and is binding.

\section{DISCUSSION}

Area 1 requires a quality curriculum to be feasible and practical. These characteristics have been identified by many authors (e.g. Janik et al., 2010, 2011; Janík, Slavík, Najvar, \& Janíková, 2019; Stabback, 2016; Thijs \& Van den Akker, 2009; and in PE Egger et al., 2002; Vlček \& Mužík, 2012). As emphasized above, when assessing for feasibility and practicability it is critical that all forms of the curriculum are considered, or, as Thijs \& Van den Akker (2009) express it, the expected and the actual.

It is clear that the health-related goals of the Czech PE curriculum are difficult to implement (Mužík \&Vlček, 2016) and have not been implemented effectively. Research

The terminology has been modified in translation to better explain the framework. 
has confirmed that curriculum reform in the Czech Republic took place largely on paper, at the documentation level; to a much lesser extent in teachers' mind-set, at the cognitive-emotional level, or in their implemented teaching (cf. Janík et al., 2018; Pešková, Spurná, \& Knecht, 2019). Hence, many PE teachers accepted curriculum reform formally, in theory, but not in practice (Vlček, 2019; Janík, Vlček, \& Mužík, 2016, p. 139). Despite the health-oriented concept clearly expressed in the Framework Educational Programme for Basic Education (FEP BE) learning objectives, most teachers are not motivated by the health-oriented PE concept and prefer a focus on sport (Fialová et al., 2014, pp. 77-83). Furthermore, research on the results and effects forms of the curriculum show that the levels of physical activity and the health status of the Czech population are unsatisfactory (cf. Antošová \& Kodl, 2014; OECD/European Observatory on Health Systems and Policies, 2017; Mitáš \& Frömel, 2013). It appears, therefore, that the $\mathrm{PE}$ curriculum is problematic presumably in part because it is not feasible and practical.

Area 2 relates to professional accuracy and congruence. Congruence (or consistency, coherence, fidelity, or alignment) has been consistently emphasized as a critical quality criterion (Stake, 1967, 1972; Dane \& Schneider, 1998; Egger et al., 2002; Thijs \& Van den Akker, 2009; Zhu, Ennis, \& Chen, 2011). Again, all five forms of the curriculum should be considered. Is the concept underpinning the curriculum congruent with the goals as expressed in the designed curriculum and the subject matter? Do teachers actually teach the designed curriculum? There are many studies which show that this is not the case in the Czech Republic. For example, there is significant incongruence between the exclusively health-oriented learning objectives of the educational area 'Man and Health' and the health-movement oriented PE content. Other research shows that the health-oriented concept form is not accepted by the public (Mužík \& Hošková, 2010; Mužík \&Vlček 2016) and is not what is being implemented (implemented form) by teachers (cf. Fialová et al., 2014; Vašíčková, 2015, Janík, Vlček, \& Mužík, 2016).

Area 3 requires a quality curriculum to be clear and comprehensible. This has been shown to be one of the most problematic areas of the Czech curriculum. Teachers have expressed the view that the PE learning objectives in the designed form are too abstract and difficult to understand (Vlček, 2011; Vlček \& Mužík, 2012). Another problem is that the FEP BE is conceptually confusing because of the lack of a clear relationship between the visionary key competences of overall basic education and the PE learning objectives and expected PE outcomes (Vlček, 2019; c.f. Knecht, 2014; Píšová, Kostková, \& Vlček, 2011), that is, it is not thoughtfully structured.

Area 4 relates to the need for a curriculum to be binding and durable but to allow the flexibility to be updated as educational content and practice changes. The two level Czech educational programmes provide considerable opportunity for free decision making by schools and teachers. However, the PE designed curriculum defined in FEP BE is not binding and does not contain a core curriculum that describes the main learning objectives and educational content of individual disciplines including PE. Therefore, there is a lack in uniformity as far as implemented curriculum is concerned (as described above) and especially in the results curriculum form in terms of learning outcomes evaluation (cf. Fialová, 2015, p. 54). 


\section{CONCLUSION}

It is clear that the quality framework presented here is consistent with the numerous research studies on curriculum quality and also with research into the PE curriculum. It is a comprehensive tool that takes account of all the different quality criteria that have been identified. It provides a tool to comprehensively assess quality y of a curriculum.

In the introduction we referenced a large body of research that indicates that the designed curriculum in the Czech Republic, including PE, is not working as it should, and that a national review is currently underway. As a part of the review process, studies for the revision of the curriculum for particular school subjects have been prepared, including a study by Tupý (2018) identifying problem areas of the PE curriculum, also in the designed curriculum. However, the issues of curriculum quality are extensive, complex, and often multifactorial (c.f. Fend, 1998, 2008; Hopmann \& Riquarts, 1995; Hopmann \& Gundem, 1998; Thijs \& van den Akker, 2009) and there are issues with all five forms of the Czech PE curriculum which should be addressed (Vlček, 2019). In our view only a comprehensive quality framework such as presented here, while developed in relation to the curriculum generally, can provide a sufficiently robust tool in the upcoming PE curriculum review and redesign in the Czech Republic.

Although we believe that a rigorous and comprehensive review of the curriculum, based on all five forms, is an essential prerequisite to a quality redesigned PE curriculum, it is important to note that comparative research (Vlček, 2019) and other texts critiquing the Czech PE curriculum (Habrdlová, Lupač, \& Vlček, 2017; Lupač, 2016; Habrdlová \& Vlček, 2015; Mužík \& Vlček, 2016; Tupý, 2018; Vlček \& Mužík, 2012) have shown that the designed PE curriculum in the Czech Republic is largely consistent with the curriculum of other developed countries in Europe and also USA. This is an important observation; it means that the Czech PE curriculum, while it may have some problems, is not fundamentally broken or significantly different from the curriculum in other countries.

\section{ACKNOWLEDGEMENTS}

This work was supported by a Faculty of Education Grant at Masaryk University 'Curriculum Research in Physical Education and Health Education for preschool education and primary school education', MUNI/A/0881/2019.

\section{REFERENCES}

Antošová, D., \& Kodl, M. (Eds.) (2014). Zpráva o zdraví obyvatel České republiky [A report on Health of the Czech population]. Prague: Ministry of Health of the Czech Republic.

Böttcher, W. (2006). 'Standards-Based Reform’ oder: Kann man für die Schul reform von den USA lernen? In: Eder, F., Gastager, A., \& Hofmann, F. (Eds.), Qualität durch Standards?, 71-84. Münster: Waxmann.

Dane, A.V., \& Schneider, B. H. (1998). Program integrity in primary and early secondary prevention: Are implementation effects out of control? Clinical psychology review, 18(1), $23-45$.

Dvořák, D. (2012). Od osnov ke standardi̊m: Proměny kurikulární teorie a praxe. Prague: Charles University. 
Dvořák, D., Starý, K., \& Urbánek, P. (2015). Malá škola po pěti letech: proměny školy v době reformy. Pedagogická orientace, 25(1), 9-31.

Egger, K., et al. (2002). Qualität des Sportunterrichts. Bern: Schriftenreihe des Instituts für Sport und Sportwissenschaft der Universitäts Bern.

Fend, H. (1998). Qualität im Bildungswesen. Schulforschung zu Systembedingungen, Schulprofilen und Lahrerleistung. Weinheim: Juventa.

Fend, H. (2008). Schule gestalten. Systemsteuerung, Schulentwicklung und Unterrichtsqualität. Wiesbaden: Verlag für Sozialwissenschaften.

Fialová, L. (2015). Pohybová gramotnost - analýza plnění standardů TV na 2. stupni ZŠ. In: Fialová, L., Kašpar, L., \& Králová, K. (Eds.), Aktualizované poznatky ke vzdělávací oblasti Člověk a zdraví (pp. 53-60). Prague: Charles University.

Fialová, L., Flemr, L., Marádová, E., \& Mužík, V. (2014). Vzdělávací oblast Člověk a zdraví $v$ současné škole. Prague: Karolinum.

Framework Educational Programme for Basich Education [FEP BE]. (2017). Prague: MEYS. Accessed November 21, 2018. http://www.msmt.cz/file/43792.

Frömel, K., Novosad, J., \& Svozil, Z. (1999). Pohybová aktivita a sportovní zájmy mládeže. Olomouc: Palacký University.

Habrdlová, M., Lupač, M., \& Vlček, P. (2017). Srovnání obsahu vybraných kurikulárních dokumentů tělesné výchovy pro primární vzdělávání v Irsku, Nizozemsku a České republice [Comparison of the PE content of the chosen primary curriculum documents in the Czech Republic, the Republic of Ireland and the Netherlands]. Pedagogická orientace, 27(3), 449-472.

Habrdlová, M., \& Vlček, P. (2015). Srovnání kurikula tělesné výchovy pro primární vzdělávání v Irsku a České republice [Comparison of physical education primary curriculum in Ireland and the Czech Republic]. Česká kinantropologie, 19(4), 34-48.

Helmke, A. (2007). Unterrichtsqualität: Erfassen, Bewerten, Verbessern. Seelze: Kallmeyersche Verlagsbuchhandlung.

Hopmann, S., \& Gundem, B. (Eds.) (1998). Didaktik and/or curriculum: An international dialogue. New York: Peter Lang.

Hopmann, S., \& Riquarts, K. (Eds.). (1995). Didaktik and/or curriculum. Kiel: IPN.

Janík, T., Janko, T., Pešková, K., Knecht, P., \& Spurná, M. (2018). Czech teachers' attitudes towards curriculum reform implementation. Human Affairs-Postdisciplinary Humanities Social Sciences Quarterly, 28(1), 54-70.

Janík, T., Knecht, P., Kubiatko, M., Pavlas, T., Slavík, J., Solnička, D., \& Vlček. P. (2011a). Kvalita školy a kurikula: Od expertniho šetřeni ke standardu kvality. Prague: NIE.

Janík, T., Knecht, P., Najvar, P., Pavlas, T., Slavík, J., \& Solnička, D. (2010). Kurikulární reforma na gymnáziích: V rozhovorech s koordinátory pilotních a partnrských škol. Prague: VÚP.

Janík, T, Slavík, J., Mužík, V., Trna, J., Janko, T., Lokajíčková, V., ... Zlatníček, P. (2016). Kvalita (ve) vzdělávání: obsahově zaměrený prístup ke zkoumání a zlepšování výuky. Brno: Masaryk University.

Janík, T., Slavík, J., Najvar, P., \& Janíková, M. (2019). Shedding the content: semantics of teaching burdened by didactic formalisms. Journal of Curriculum Studies, 51(2), 185-201.

Janík, T., Vlček, P., \& Mužík, V. (2016). Implementace kurikulární reformy v České republice: obecné problémy konkretizované pohledem na kurikulum tělesné výchovy [Implementig curricular reform in the Czech Republic: general issues in the light of Physical Education curriculum]. In: Porubský, Š. et al. Premeny školského kurikula: slovenská a česká skúsenost' (pp. 131-141). Banská Bystrica: Belianum.

Knecht, P. (2014). Přiležitosti k rozvijení kompetence $k$ řš́ení problémů v učebnicích a ve výuce zemépisu. Brno: MU.

Kuhn, J. (2011). Kurikulární reforma v poločase. Pedagogická orientace, 21(4), 480-486. 
Kuřina, F. (2014). Kompetence a školní praxe. Rozpaky oborového didaktika nad kurikulární reformou. Pedagogická orientace, 24(3), 434-443.

Lawton, D., \& Gordon, P. (1993). Dictionary of education. London: Hodder Stoughton.

Lupač, M. (2016). Obsahová analýza kurikulárních dokumentů tělesné výchovy v Nizozemsku z hlediska vybraných faktorů kvality projektovaného kurikula: komparace s RVP ZV [The content analysis of Dutch PE projected curricula from perspective of chosen curricula factors of quality: comparison with Czech PE designed curricula]. Studia sportiva, 10(1), $15-32$.

Mitáš, J., \& Frömel, K. (2013). Pohybová aktivita české dospělé populace v kontextu podmínek prostredí [Physical aktivity of the Czech adult population in the setting context]. Olomouc: Palacky University.

Mužík, V., \& Hošková, L. (2010). Názory žáků základní školy na realizaci kurikula tělesné výchovy. In: Mužík, V., \& Vlček, P., et al. Škola, pohyb a zdraví: výzkumné výsledky a projekty (pp. 75-92). Brno: MU.

Mužík, V., \& Vlček, P. (2016). Proměny tělovýchovných koncepcí a jejich vliv na realizaci obsahu vzdělávání v tělesné výchově [Conceptual Changes in Physical Education and Their Influence on the Realisation of Physical Education Content]. Orbis scholae, 10(2), 131-143.

OECD/European Observatory on Health Systems and Policies (2017). Česká Republika: zdravotni profil zemé 2017 [The Czech Republic: the health profile of the country 2017]. State of Health in the EU, OECD Publishing Paris/European Observatory on Health Systems and Policies, Brussels. Accessed January 21, 2019.

Pešková, K., Spurná, M., \& Knecht, P. (2019). Teachers' acceptance of curriculum reform in the Czech Republic: One decade later. Center for Educational Policy Studies Journal, 9(2), 73-97.

Píšová, M., Kostková, K., \& Vlček, P. (2011). Kurikulární reforma na gymnáziích: případové studie. In: Janík, T., Knecht, P., \& Šebestová, S. (Eds.), Smíšný design v pedagogickém výzkumu: Sborník př́spèvků z 19. výroční konference České asociace pedagogického výzkumu (pp. 24-30). Brno: MU.

Průcha, J. (1996). Pedagogická evaluace. Brno: Masaryk University.

Průcha, J. (2002). Moderní pedagogika. Prague: Portál.

Stake, R. E. (1967). The countenance of educational evaluation. Teachers College Record 68, $523-540$.

Stake, R. E. (1972). Verschiedene Aspekte pädagogischer Evaluation. In: Wulf, CH. Evaluation. Beschreibung und Bewertung von Unterricht, Curricula und Schulversuchen (pp. 92-112). München.

Šíp, R. (2014). Problematické aspekty současné pedagogiky z pohledu pedagogické filozofie: vztah praxe a teorie a potlačení somatické dimenze pedagogických procesủ. Habilitační práce. Brno: MU.

Terhart, E. (2000). Qualität und Qualitätssicherung im Schulsystem. Hintergründe - Konzepte Probleme. Zeitschrift für Pädagogik, 46(6), 809-829.

Thijs, A., \& van den Akker, J. (Eds.). (2009). Curriculum in development. Enschede: SLO.

Vašičková, J. (2016). Pohybová gramotnost v České republice [Physical literacy in the Czech Republic]. Olomouc: Palacky University.

Vlček, P. (2011). Pohledy na kurikulum tělesné výchovy aneb co je vlastně cílem současné tělesné výchovy? In: Píšová, M., Kostková, K., Janík, T., Doulík, P., Hajdušková, L., Knecht, P ... Vlček, P. Kurikulární reforma na gymnáziích - př́padové studie tvorby kurikula (pp. 175-199). Prague: VÚP.

Vlček, P. (2019). Reviewing the Physical Education curriculum in the Czech Republic. Logos Verlag: Berlin. 
Vlček, P., \& Janík, T. (2010). Školské reformy a tvorba kurikula tělesné výchovy v České republice, Spolkové republice Německo a Spojených státech amerických [School reform and PE curriculum design in the Czech Republic, Germana and the USA]. Brno: Paido.

Vlček, P., \& Mužík, V. (2012). Soulad mezi projektovaným a realizovaným kurikulem jako faktor kvality vzdělávání v tělesné výchově [Congruence between projected and realidsed curriculum as a factor of quality in PE]. Česká kinantropologie, 16(1), 31-45.

Zhu, X., Ennis, C. D., \& Chen, A. (2011). Implementation challenges for a constructivist physical education curriculum. Physical Education and Sport Pedagogy, 16(1), 83-99. 